\section{Dr. Ian Speden}

\section{IUGS Vice President}

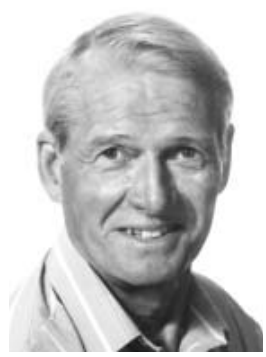

Ian was born in 1932 in Gore, southern New Zealand, where he attended primary and secondary school. In 1950, he went to the University of Otago, Dunedin, graduated BSc. in geology and botany in 1954, and continued to complete an MSc. (1st Class Hons.) in geology in 1956. This was based on a field mapping, sedimentological and paleontological thesis covering Early and Middle Jurassic sequences in the little known Catlins District, South-East Otago.

He joined the Invercargill District Office of the NZ Geological Survey (NZGS), Department of Scientific and Industrial Research (DSIR), in December, 1956, to complete mapping for a monograph on the Papatowai 1:63,660 sheet and to contribute to the 1:250,000 Geological Mapping Programme. In September 1957, he was transferred to the Head Office of NZGS, Wellington. During the summer of 1958-59 he was a member of the second NZGS Antarctic Expedition to the McMurdo Sound region where he was involved in mapping projects. In 1961, he was awarded a National Research Fellowship for a $\mathrm{PhD}$ (1961-1964) at Yale University, USA, for research on the taxonomy and paleoecology of the Bivalvia of the Fox Hills Formation (Maastrichtian), South Dakota, under Professor Karl Waage.

Ian returned to NZ in early 1965 , after two months at four universities in Japan studying Jurassic bivalves as a basis for taxonomic and paleogeographic studies of New Zealand and circum-Pacific faunas. On his return to NZ he commenced integrated field and laboratory studies on the geological history of the Cretaceous, a time of major change in tectonic processes and events, and the formation of sedimentary basins important for coal and hydrocarbon resources. Over the next 12 years Ian gained wide experience of the complex sequences of Raukumara Peninsula, Wairarapa and Marlborough. Geological information and knowledge obtained has been applied to an extensive range of resource, erosion and development issues. In June and July 1968, Ian spent two months at the Geology Department, Australian National University, Canberra, as a visiting lecturer to present courses on paleoecology and taxonomy.

During this early stage of his career Ian was active in the work of the Geological Society of NZ, including a term (1973-1974) as President. His interest in international stratigraphic correlation resulted in his attendance as the $\mathrm{NZ}$ representative at the IUGS/UNESCO meeting in Budapest, August, 1968, which initiated the International Geological Correlation Programme. After that meeting he visited geological institutions in Moscow and Leningrad to examine Jurassic bivalves from Siberia as a basis for paleogeographic studies, and contributed to the work of the International Subcommission on Stratigraphic Classification in the preparation of the Hollis Hedberg edition of the International Stratigraphic Guide (1976). He was appointed the Chairperson of the NZ National Committee for IGCP, a position he held until 1994, and participated in a joint BRGM and NZ IGCP project (1976-1978) on the biostratigraphy of the Southwest Pacific region. In 1976, Ian attended his first International Geological Congress in Sydney, Australia.

In 1977, Dr. Speden was appointed Regional Geologist responsible for mapping programmes, primarily special mapping projects and District Offices, and for environmental reporting and Town and Country Planning. Through this work he developed a wide interest in the application of geology and the transfer of information to users. He contributed extensively to the DSIR Discussion Paper No.3 "Land Alone Endures" (1980), an important source of information and principles on land use. During 1978-1981 he was a member of the National Committee for UNESCO when he co-convened the preparation of a resource volume on "Natural Hazards in New Zealand" (1984). In 1981, Ian spent a month visiting the Reston and Menlo Park offices of the USGS to study the state of development of national databases, Geographic Information Systems and the transfer to and the use of information by decision makers. In 1983, he convened for the Minister for the Environment a Working Party to review the implementation and results of "Environmental Audits and Appraisals 1976-81". For his research before and during this period Ian was elected in 1980 a Fellow of the Royal Society of NZ (Academy of Science).

Dr. Speden was appointed Director of NZGS in October, 1984, and managed the Division through a period of major policy and administrative change, and declining government funding. During this time the Division significantly increased its number of scientific publications and client reports, and also more than doubled its commercial revenue. Ian was a member of the Ross Dependency Research Committee (Antarctica; RDRC) from 1984 to 1992, and continued to develop contacts with international geoscience agencies, including through participation in the work of the annual Australian Chief Government Geologists Conference, and the Council of the Royal Society of NZ (1984-1988) when he was its Honorary Treasurer. In 1989, Ian attended his second International Geological Congress in Washington DC, USA, before and after which he visited the Geological Survey of Canada, USGS and the British Geological Survey to further contacts and to assess GIS development and information management. Earlier that year he led a small team of NZ geoscientists on a visit to the Chinese Ministry of Geology and Mineral Resources and its institutes in Beijing, Wuhan and Guangzhou to develop joint projects.

With the restructuring in 1990 of DSIR from 23 to 10 Divisions, Ian was appointed Director of DSIR Geology and Geophysics. For six months in 1992 he was Acting Chairman of RDRC. Following restructuring of government science organisations in 1992, Dr. Speden became Group Manager of Geological Mapping and Information in the new Crown Research Institute, the Institute of Geological \& Nuclear Sciences (GNS).

In June 1994 Ian retired after 37.5 years service, during which his research resulted in over 110 papers, including five monographs and three geological maps. Presently, Ian is an Honorary Research Associate with GNS undertaking research projects related to regional geology and the revision of the Geological Map of NZ $1: 250,000$. He served a second term (1997-2000) on the Council of the RSNZ and in 1996, when he attended the 30th IGC in Beijing, China, Ian was elected a Vice President of IUGS. He considers himself privileged to have had the opportunity to contribute to the diverse and important activities of the Union.

\author{
Address: \\ Dr. Ian G. Speden \\ IUGS Vice President \\ Institute of Geological and Nuclear Sciences \\ P.O. Box 30-368 \\ Lower Hutt \\ NEW ZEALAND \\ Tel: +64 45701444 \\ Fax: +64 45690600 \\ E-mail: i.speden@gns.cri.nz
}

